\title{
KONTRAK SOSIAL MENURUT IMMANUEL KANT: KONTEKSTUALISASINYA DENGAN PENEGAKAN HAM DI INDONESIA
}

\author{
Althien J. Pesurnay \\ Universitas Kristen Duta Wacana \\ Email: althienjohn@staff.ukdw.ac.id
}

\section{Abstrak}

Penegakan HAM masih menjadi persoalan bangsa Indonesia. Pemerintah sebagai penyelenggara kehidupan bernegara dan berbangsa belum menunjukkan kehendak tegas dan komitmen kuat untuk menegakkan dan melindungi HAM di Indonesia. Tercatat sejumlah pelanggaran HAM masih sering terjadi di era pasca reformasi. Kasus-kasus pelanggaran HAM masa lalu juga belum terselesaikan. Artikel ini ditulis dengan dua alasan. Pertama, fenomena penegakan dan penyelesaian kasus HAM di Indonesia masih dianggap sebagai isu publik yang sensitif untuk dibicarakan. Kedua, kasus HAM lebih sering dibahas dari sudut pandang sejarah dan hukum. Artikel ini mencoba mencari prinsip dasar kontrak sosial yang dapat dikontekstualisasikan dengan penegakan dan perlindungan HAM di Indonesia. Artikel ini menganalisis konsep kontrak sosial dari perspektif filsafat politik Immanuel Kant. Kebebasan dan kesetaraan merupakan prinsip dasar bagi HAM yang dalam pemikiran Immanuel Kant merupakan hak alamiah sehingga perlu dilindungi dengan perangkat prosedur filsafat moral. Konsep kontrak sosial Kant linier dengan filsafat moralnya yang bersifat murni rasional. Kontrak baginya merupakan penyatuan kehendak. Negara melalui pemerintah bertugas menjalankan kehendak publik untuk mengatur dan memberi kepastian hukum untuk menjamin kebebasan dan kesetaraan bagi setiap individu dalam kerangka HAM.

Kata kunci: Kontrak Sosial, Penyatuan Kehendak, Kebebasan, Kesetaraan, HAM 


\section{Abstract}

This article addresses a sensitive topic within issues of human rights in Indonesia through a Kantian perspective. Cases of human rights violations are a common occurrence in Indonesia. Human rights violations in the country are largely assessed from historical and legal perspectives. However, there is little commitment or willingness on the part of the Indonesian government to protect and defend the principles of human rights. This article attempts to employs arguments adopted from Immanuel Kant's philosophical system as a way to contextualize the protection and implementation of human rights in Indonesia. It employs an analysis of the concept of social contract in Immanuel Kant's political philosophy. According to Kant, freedom and equality are natural rights. Both are human rights basic principle. This article demonstrates that Kant's social contract theory is linear with his formal moral philosophy. In his explanation, 'contract' is unified will. Therefore, the state with its power is responsible to implement the will of the public to ensure order and rule of law and to protect the rights, equality and freedom of each individual.

Keywords: Social Contract, Unified Will, Freedom, Equality, Human Rights.

\section{PENDAHULUAN}

Penegakan HAM di Indonesia pasca reformasi tidak mengalami perubahan signifikan meski terjadi proses demokratisasi pasca berakhirnya pemerintahan otoritarian. Hasil penelusuran peneliti dari komnas HAM, organisasi nonpemerintah, dan media arus utama menunjukkan fakta pelanggaran HAM di Indonesia masih sering terjadi. Pelanggaran HAM umumnya dibagi ke dalam dua yakni kategori ringan dan berat. Kasus dengan kategori ringan seperti pelanggaran mengekspresikan pendapat, pembubaran acara diskusi, pelanggaran kebebasan beribadah dan berkeyakinan masih terus terjadi. Kategori kasus pelanggaran HAM berat seperti pembunuhan dan penghilangan orang secara paksa juga tercatat masih ada. Kasus-kasus HAM berat masa lalu tidak kunjung terselesaikan hingga hari ini. Pada tahun 2019 yang lalu bahkan komnas HAM mengirimkan catatan kepada pemerintah yang berisi 
tiga hal penting terkait pelanggaran HAM berat, konflik agraria, diskriminasi dan intoleransi (Egi, 2018).

Menurut Komnas HAM dilansir dari media arus utama Kompas, belum ada langkah progresif kasus-kasus pelanggaran berat oleh negara (Deti, 2019). Pelanggaran HAM kategori ringan masih sering terjadi namun hanya menjadi konten berita di media. Dilansir lewat situs resmi Komnas HAM disimpulkan bahwa penegakan HAM di Indonesia belum mengalami kemajuan. Lanjutnya, Rencana Aksi Nasional Hak Asasi Manusia (RANHAM) juga belum menunjukkan pencapaian yang signifikan (Utari, 2020). Selain Komnas HAM lembaga-lembaga yang diakui kredibel dan berdedikasi pada isu-isu HAM seperti YLBHI, Kontras, ELSAM, Human Right Watch, SETARA Institut, Lokataru, Amnesty International Indonesia rutin mempublikasikan laporan tahunan, pernyataan dan catatan kritis. Secara argumentatif informasi, kajian, dan laporan dari lembaga-lembaga tersebut menunjukkan bahwa penegakan HAM di Indonesia memang belum menunjukkan kemajuan yang pesat. Senada dengan amatan Komnas HAM dan laporan rutin lembaga-lembaga tersebut bagi Hariz Azhar, kondisi penegakan HAM di Indonesia cenderung lemah dan lambat (Azhar, 2014). Belum muncul inisitiatif besar dari dalam. Penegakan HAM di Indonesia terdesak jika diketahui dunia internasional. Faktor dari luar membantu perbaikan HAM di dalam. Sedangkan di dalam sendiri terjadi stagnasi. Inisiatif yang lemah dari dalam negeri menjadi faktor utama yang menyebabkan lambatnya progres penegakan HAM di tanah air. Selain itu, pemerintah lebih sering menggunakan HAM sekedar sebagai bahasa universal namun tidak dipraktikkan atau ditegakkan (Azhar, 2014).

Indonesia memiliki banyak hambatan untuk menegakkan HAM. Retorika penegakan HAM sulit dibuktikan secara koresponden dengan kenyataan jumlah laporan dugaan pelanggaran HAM yang masih kerap muncul. Harapan adanya kebijakan dari pemerintah untuk mengurangi pelanggaran atas HAM belum terwujud. Situasi yang terjadi adalah sebaliknya. Menurut Haris Azhar pemerintah justru menunjukkan perilaku 
korup, penyalahgunaan, mentalitas kekerasan oleh publik dan aparat keamanan (Azhar, 2014). Keadaan tersebut bersumber dari kelemahan pemerintah dan ketiadaan kehendak untuk menjunjung dan menegakkan HAM.

Selain pemerintah, dari aspek publikasi dan informasi HAM tidak menjadi wacana dominan dan membawa dampak signifikan. Media jarang menjadikan HAM sebagai topik utama dan headline berita. Media belum terbukti berperan sebagai pengawas terhadap penyelenggaraan pelaksanaan hidup berbangsa bernegara. Media belum menjalankan tugas menjadi watchdog bagi publik. Kekosongan wacana HAM di media membuat sebagian masyarakat yang kurang memberi perhatian bagi mereka yang terkena dampak dari lemahnya penegakan hukum. Isu HAM hanya menjadi isu bagi mereka yang terdampak (Azhar, 2014). Keadaan ini menambah kompleksitas persoalan HAM dan sekaligus menyumbang pertanyaan tentang jalan keluarnya.

Secara mendasar pengetahuan tentang HAM perlu diurai dan dipikirkan kembali. Artikel ini bermaksud mengkaji dan mengurainya secara filosofis. HAM jika dikaji dari sudut pandang filsafat maka bersentuhan langsung dengan dimensi moral dan sosial-politik manusia. Oleh sebab itu fenomena penegakan dan perlindungan HAM ini akan dibahas dari sudut pandang filsafat politik. Terdapat dua alasan mendasar artikel ini dibuat. Pertama, kasus HAM di Indonesia masih dianggap isu sensitif untuk dibahas dan ditindaklanjuti agar bisa menghasilkan agenda penegakan, penyelesaian dan resolusi. Hambatan penuntasan kasus-kasus HAM di Indonesia secara mendasar menyangkut ketiadaan kehendak politik untuk menyelesaikannya. Perlu ada niat besar untuk mencari mekanisme dan prosedur penyelesaian persoalan HAM. Secara teknis diakui oleh pejabat lembaga yudikatif bahwa kasus-kasus pelanggaran HAM berat yang terjadi di masa lampau sulit dibuktikan sebab masalah alat bukti maupun tempat kejadian yang telah berubah. Pada level kekuasaan, pelanggaran HAM berat terjadi melibatkan institusi negara, elit-elit politik dan militer. 
Jaringan kekuasaan elit di pemerintahan yang bercokol sejak awal reformasi hingga sekarang.

Kompleksitas permasalahan HAM di Indonesia perlu dikaji secara serius dan berkelanjutan dengan menggunakan sudut pandang yang kritis-rasional. Dari perspektif filsafat politik kompleksitas persoalan HAM secara khusus membutuhkan tinjauan ulang tentang dalil-dalil dasar kebebasan, hak individu, interaksi sosial kemasyarakatannya dalam satu negara. HAM berhubungan dengan dalil hak dasar dan martabat manusia. Keberhasilan kebijakan yang menjunjung serta melindungi HAM menunjukkan kualitas dan martabat suatu negara dan bangsa. Penting sekali untuk menelaah kembali status dan fungsi negara dalam menegakkan supremasi hukum dan melindungi setiap warga negara. Alasan kedua artikel ini ditulis adalah untuk memberi kontribusi bagi wacana HAM di Indonesia dari segi kefilsafatan karena HAM dalam konteks Indonesia secara kuantitatif lebih banyak dibahas dari aspek yuridis dan kesejarahan. Adapun tulisan ini akan berfokus pada pembahasan HAM dari perspektif filsafat politik, khususnya melalui pemikiran Immanuel Kant.

\section{APA ITU HAK ASASI MANUSIA?}

HAM sebagai singkatan dari hak asasi manusia umum terdengar dalam kehidupan sehari-hari. Masyarakat awam menyebut HAM secara sederhana dengan maksud menunjuk "hak". Masyarakat awam belum secara lengkap memahami HAM secara konseptual ataupun historis. HAM biasanya diucapkan seseorang secara eksplisit untuk mengklaim hak-haknya. HAM diucapkan dalam keadaan ketika individu, kelompok atau yang mewakilkan merasa bawah ada hak yang terancam, terdiskriminasi, terpinggirkan, dan atau direpresi. HAM dirasa terganggu ketika ekspresi kebebasan, hak, kepercayaan, tradisi, kebudayaan, gaya dan pilihan hidup dilanggar oleh pihak lain. Adapun beberapa pelanggaran HAM yang termasuk kategori berat antara lain penghilangan nyawa, kepemilikan tempat tinggal, dan atau 
pengalaman kekerasan tanpa proses dan perlindungan hukum. Kondisi-kondisi tersebut lantas mendorong adanya uraian yang lebih lengkap tentang apa sebenarnya HAM secara konseptual. Sejak kapan Indonesia sebagai bangsa mulai mempraktikkan perlindungan HAM? Kerangka koseptual dan historis HAM dalam konteks Indonesia lantas perlu dipaparkan lebih lanjut.

Hak asasi manusia dalam bahasa inggris disebut human rights. Frasa tersebut diterjemahkan secara sederhana dari kamus Oxford berarti hak dasar bagi setiap orang untuk diperlakukan wajar dan baik terkhusus oleh pemerintahnya. Human rights sebagai gagasan dapat dimaknai sebagai suatu ide politik dan moral yang diterima secara universal (Gordon, 2017). HAM secara konseptual merupakan hasil konsensus dinamis yang berkembang dalam sejarah cukup panjang. HAM jika ditelusuri idenya lebih lebih tua dari peristiwa lahirnya Magna Charta tahun 1215. Magna Charta sendiri berisi pengaturan hak-hak yang masih sangat sederhana. Evolusi konseptual dari HAM secara historis terus berlangsung sampai sekarang.

Jack Donnely professor teori politik dalam karyanya berjudul Universal Human Rights in Theory and Practice (2003) mendefinisikan HAM sebagai hak-hak yang dimiliki manusia pada dirinya. HAM menurutnya bukanlah sesuatu yang diberikan oleh masyarakat ataupun hukum positif. HAM dimiliki setiap individu berdasarkan martabatnya sebagai manusia (Donnelly, 2019). HAM dalam perkembangannya kemudian menjadi bagian dari terminologi hukum karena beririsan dengan wacana kewarganegaraan (citizenship) dalam bingkai negara hukum. Persoalan HAM secara teoritis berada di tengah konflik antara doktrin moral, politik dan hukum serta penggunaan tindakan negara terkait ketiga doktrin tersebut (Freeman, 1994). HAM dalam konteks masyarakat global kontemporer secara historis dideklarasikan di Paris, Perancis, pada tahun 1948. Deklarasi HAM universal menghasilkan 30 pasal mengenai hak-hak kesetaraan, harkat dan martabat setiap manusia sebagai individu. 
Bangsa Indonesia patut berbangga sebab dalam kondisi awal pasca kemerdekaan, HAM telah menjadi diskursus berbangsa dan bernegara. Kehidupan sosial masyarakat Indonesia telah ada berdasarkan ikatan yang moral dan legal. Indonesia sebagai negara hukum modern dapat dikatakan dibangun dengan kesadaran tentang HAM. Kesadaran tersebut termuat dalam pembukaan dan batang tubuh UUD 1945. HAM secara implisit juga terkandung dalam sila kedua, keempat dan kelima Pancasila sebagai falsafah bangsa. Dasar negara dan konstitusi Indonesia telah mengafirmasi nilai-nilai kemanusiaan, hak tentang partisipasi politik, kesejahteraan dan keadilan sosial.

HAM sangat erat terikat dengan dimensi politik dan hukum. Dimensi politik dalam sejarah Indonesia bergerak dinamis. HAM pada awal kemerdekaan Indonesia termuat secara implisit dalam 8 pasal yang belum terperinci dan tidak menggunakan kosa kata hakhak (Budiardjo, 1981). Jika ditelusuri lebih detail terdapat 15 prinsip HAM yang terkandung dalam pembukaan hingga batang tubuh UUD 1945 (El-Muhtaj, 2015). Wacana HAM kemudian menguat pada era konstitusi RIS (1949) karena faktor euforia Deklarasi Universal Hak Asasi Manusia (DUHAM) pada 10 Desember 1948. Konstitusi RIS memuat 27 pasal yang sangat menekankan signifikansi HAM. Konstitusi RIS 1949 tidak hanya mengenai hakhak dan kebebasan dasar manusia tetapi juga mengatur kewajiban asasi negara dalam kerangka penegakan HAM (El-Muhtaj, 2015). Terdapat pula sub bagian khusus tentang hak-hak dan kebebasankebebasan dasar manusia (Putra, 2016). Wacana HAM dalam perkembangan Konstitusi Indonesia berlanjut kemudian ke UUDS di tahun 1950. Konstitusi dalam perkembangannya tidak hanya menjunjung hak-hak asasi individual tetapi juga menekankan fungsi dan manfaat sosial (El-Muhtaj, 2015). Perkembangan tersebut secara sederhana berarti prinsip-prinsip hak asasi bekerja dengan maksud sosial.

Perlindungan HAM merupakan prasyarat bagi berjalannya konsep negara hukum demokratis. Kegagalan perlindungan dan penghormatan HAM merupakan dekadensi bagi suatu negara 
hukum. Sebagai contoh pada orde baru terdapat banyak fakta bahwa HAM sipil dan politik dilanggar demi menjaga stabilitas politik (Aswandi \& Roisah, 2019). Setelah rezim otoriter Suharto berakhir di era reformasi wacana penegakan HAM mendapatkan angin segar. Reformasi menjadi momen harapan baru bagi kelompok masyarakat sipil demokratis, mahasiswa, aktivis dan akademisi yang memahami urgensi HAM.

Harapan tentang penegakan dan penyelesaian kasus HAM secara maksimal di Indonesia belum terpenuhi. Setelah dua dekade berakhirnya pemerintahan otoriter terbukti belum ada kemajuan dalam konteks hukum bagi penegakan ataupun penyelesaian kasus HAM masa lalu. Usman Hamid sebagai pakar hukum tata negara menyatakan bahwa di era reformasi belum tampak perkembangan pesat terkait HAM (Hamid, 2006). Kondisi politik sangat mempengaruhi praktik yuridis. Kondisi politik hukum di Indonesia berkorelasi dengan proses demokratisasi Indonesia yang cenderung lamban. Haris Azhar seorang aktivis HAM kawakan menyatakan hal serupa, bahwa kondisi penegakan HAM di Indonesia cenderung lemah dan lambat (Azhar, 2014). Masalah tersebut terletak pada kelemahan pemerintah ketika berhadapan dengan kasus-kasus yang melibatkan aktor-aktor yang memiliki kekuasaan dan pengaruh politik. Selain itu pemerintah juga belum menunjukkan kehendak kuat serta komitmen besar untuk menegakkan dan menjunjung tinggi HAM.

\section{HAM DALAM TERANG FILSAFAT POLITIK}

Filsafat merupakan ilmu pengetahuan yang sangat tua. Secara etimologi filsafat berasal dari kata "philein" yang berarti mencintai dan "sophos" yang berarti bijaksana. Sehingga secara singkat filsafat diartikan sebagai mencintai hal-hal yang bersifat bijaksana. Sedangkan politik berasal dari kata "polis". Kata "polis" mengacu pada negara kota dan dunia kehidupan masyarakat (Bertens, 1975). Politik di era kontemporer lebih dimengerti sebagai konsep yang terkait dengan negara, hukum, warga, kebijakan dan kekuasaan. Politik erat kaitannya dengan kebijakan negara dan kehidupan 
masyarakat di dalamnya. Filsafat politik merupakan turunan dari etika dan dikategorikan sebagai filsafat praktis. Filsafat politik berbeda dengan ilmu politik karena secara fundamental bertumpu pada segi normatif. Filsafat politik merupakan cabang filsafat yang mengkaji segi normatif dari politik secara rasional dan sistematik (Rapar, 1993). Filsafat politik berisi ulasan, gagasan, usulan, tawaran, evaluasi normatif tentang dimensi sosial dan politik manusia.

Percakapan tentang politik kontemporer tidak lengkap apabila tidak menyentuh isu demokrasi. Demokrasi sebagai sistem politik dan prinsip dasar merupakan topik hangat dalam rangka menilai suatu negara hukum modern. Sebagai sistem politik yang paling banyak dianut di dunia, demokrasi sejauh ini secara luas dianggap sebagai gagasan yang paling baik. Pengkajian atas penegakan HAM dari kacamata filsafat politik otomatis akan beririsan dengan pembahasan demokrasi. HAM dan demokrasi memiliki keterkaitan erat sehingga terkadang keduanya dianggap sebagai konsep kembar (Landman, 2018). Demokrasi dan HAM secara historis memiliki persamaan pokok yakni perjuangan kebebasan, kesetaraan dan hak-hak warga negara. Filsafat politik secara umum bertugas menguji pokok-pokok tersebut. Filsafat politik memeriksa, menyoal, mengevaluasi konsep-konsep seperti kebebasan, kesetaraan, keadilan, hak, hukum, dan legitimasi kekuasaan secara filosofis dan normatif.

Pembahasan HAM dari perspektif filsafat politik yang komprehensif tentu akan menyentuh pembahasan tentang negara, hukum, dan legitimasi bagi pengaturan kehidupan negara yang beradab, bermoral dan bermartabat. Penjaminan prinsip dasar HAM seperti kebebasan, hak-hak dan kesetaraan mengandaikan adanya satu tatanan politik dan hukum yang stabil. Tatanan tersebut berupa kesepakatan yang dalam filsafat politik dikenal sebagai kontrak sosial. Tujuan kontrak sosial adalah menjamin agar warga maupun pemerintah tidak bertindak sewenang-wenang dan melanggar hak serta kebebasan yang dimiliki individu. Negara berkewajiban melindungi HAM setiap warganya. Imperatif moral 
politik tersebut akan dielaborasi dan dianalisis dengan perspektif filsafat politik, khususnya dalam kerangka kontrak sosial.

Kontrak sosial sebagai salah satu tema utama dalam filsafat mulai dipopulerkan sejak era filsafat modern. Tiga filsuf politik yang paling dikenal dengan idenya mengenai sosial kontrak adalah Thomas Hobbes, John Locke, dan J.J. Rousseau. Gagasan kontrak sosial pada dasarnya mengacu pada semacam kesepakatan, perjanjian yang dibuat satu orang dengan yang lain untuk menjamin rasa aman. Kontrak dalam pemikiran Hobbes secara sederhana berarti kesepakatan yang dibuat sejumlah orang yang hidup bersama di dalam lembaga berdaulat yang memegang otoritas untuk menyelesaikan masalah keadaan alamiah (Russel, 1945). Kontrak berbentuk aturan yang menjamin kehidupan manusia damai dan aman. Kontrak diasumsikan akan membawa kehidupan sosial yang berbeda dari keadaan alamiah. Aturan itu bekerja dengan maksud menghindari bahaya dengan menjalankan kebaikan tertinggi. Negara dan penguasa berdaulat di atas semua orang dalam menerapkan hukum. Manusia yang memahami hukum alam dan hak-haknya akan bersedia membuat kontrak sosial. Secara implisit manusia membutuhkan kekuatan eksternal untuk menjamin agar dirinya tetap setia pada kontrak. Kontrak dalam bentuk perjanjian inilah yang kemudian mengukuhkan peran negara sebagai otoritas publik (Schmandt, 1960).

Berbeda dengan Hobbes, asumsi keadaan alamiah Locke tidak ekstrim. Masyarakat diandaikan bebas tapi rasional dan berbudaya (Schmandt, 1960). Dalil keadaan alamiah tersebut membuat kontrak sosial versi Locke menjadi berbeda. Menurut Locke setiap orang menyerahkan kekuasaan kepada komunitas politik. Komunitas politik ini berupa pemerintahan yang memperoleh persetujuan dari setiap orang. Lebih lanjut dijelaskan bahwa kekuasaan tidak diberikan kepada satu otoritas eksternal yaitu negara karena Locke menolak segala macam pemerintahan yang bersifat absolut. Locke menyarankan pemerintahan yang konstitusional (Schmandt, 1960).

Selain Thomas Hobbes dan John Locke, Jean Jaques Rousseau juga merupakan peletak dasar kontrak sosial. Rousseau 
menerbitkan karya dengan judul Social Contract pada tahun 1762. Menurut Rousseau keadaan alamiah bersifat tidak pasti. Ada masa di mana individu tidak dapat bertahan hidup dengan kebebasan alamiahnya. Individu dengan individu yang lain mengatasi ketidakpastian tersebut dengan cara membentuk suatu masyarakat. Individu-individu kemudian mencari perlindungannya dalam kesepakatan untuk menjadi sebuah masyarakat. Masyarakat sebagai asosiasi berfungsi melindungi dan menjaga setiap individu dan kepemilikannya. Asosiasi ini dibentuk oleh tiap individu yang ikut di dalamnya. Individu tetap menjadi individu yang bebas, ia menaati dirinya sendiri lewat kesepakatan dan kontrak itu sendiri (Russel, 1945). Dengan kata lain individu tetap bebas dan mendapatkan kepastian akan jaminan keamanan.

Gagasan kontrak sosial dari ketiga filsuf politik di atas menunjukkan bahwa pembahasan tentang HAM tidak dapat dilepaskan dari konsep dasar kontrak sosial itu sendiri. Jaminan keamanan, peran negara, kebebasan, kesetaraan merupakan dasardasar prinsipil bagi penegakan HAM. Jauh sebelum DUHAM tahun 1948 menjadi standar pasal-pasal terkait HAM para filosof modern telah merefleksikan prinsip-prinsip bagi hak-hak dan kebebasaan manusia dalam melalui gagasan kontrak sosial. Kesadaran akan kondisi alamiah, hukum alam, hak alamiah dan perlunya kesepakatan memuncak menjadi kontrak sosial. Kontrak sosial bertujuan mengatur kesetaraan, kebebasan, dan hak sehingga dapat dikatakan linier dengan prinsip-prinsip dasar HAM. Kondisi alamiah bahkan dapat dibayangkan sebagai kondisi tanpa jaminan atas HAM. Secara hipotetis dalam keadaan alamiah (state of nature) kehidupan manusia sangat tidak menentu, mencemaskan dan beresiko. Kontrak sosial lantas menjadi jalan untuk mengatur beragam hak manusia dalam satu masyarakat. Kontrak sosial menjadi landasan konseptual untuk mewujudkan satu tatanan sosial politik yang bermartabat. Kontrak menjadi fondasi dan legitimasi untuk mengatur hubungan antar individu dan haknya.

Kontrak sosial dalam rumusan ketiga filsuf politik tersebut dapat dijadikan sebagai gambaran awal bagi perenungan cara 
bagaimana mewujudkan satu tatanan hidup masyarakat yang melindungi hak-hak dan kebebasan anggotanya. Negara dan konstitusi sebagai bentuk atau wujud dari kontrak sosial memiliki fungsi menegakkan dan menjamin hak-hak alamiah. Pemerintahan dan hukum merupakan manifestasi konkret kesepakatan penjaminan kehidupan sosial kemasyarakatan yang bermoral. Uraian dari gagasan kontrak sosial menjadi gambaran bagi pemahaman atas HAM lebih lanjut. Bahwa sifat universalitas, kesetaraan, kemelekatan (inalienable), ketakterpisahan (Indivisibility), serta sifat non-diskriminatif HAM dalam konteks Indonesia perlu dianalisis kembali, khususnya dengan perspektif filsafat politik Immanuel Kant.

\section{IMMANUEL KANT: SELAYANG PANDANG}

Betrand Russel pernah menyatakan bahwa sangat aneh jika tidak mengenal seberapa pentingnya Immanuel Kant dalam sejarah filsafat (Russel, 1945). Immanuel Kant Lahir di Konigsberg 1724 dan tidak pernah bepergian dari kota tersebut. Immanuel Kant dibesarkan dalam keluarga keturunan Skotlandia yang pietis. Semasa sebelum berkuliah ia hidup dengan sungguh-sungguh menjunjung tinggi kesalehan. Namun terjadi perubahan besar setelah Kant belajar di universitas.

Kant mahir dalam bahasa latin mengingat ketertarikannya kepada ilmu pengetahuan alam dan sekolah formal pada masa itu mewajibkan mempelajari bahasa latin. Jika diperhatikan terdapat banyak terminologi dalam bahasa latin pada karya-karyanya. Kant mulai masuk universitas sejak 1732-1740. Semasa kuliah Kant diajar oleh seorang professor logika dan metafisika Martin Knutzen yang tidak lain adalah murid dari Christian Wolf (Copleston, 1994). Secara intelektual Kant dididik dalam tradisi Wolfian yang juga adalah pengikut Leibniz.

Pemikiran awal Kant lebih banyak mengenai ilmu alam. Kant mempelajari karya-karya Izaac Newton, Laplace dan Leibniz. Fase pemikiran Kant ini disebut oleh para penilitinya sebagai fase pra- 
kritis. Kant melamar untuk meneruskan posisi Martin Knutzen sebagai professor akan tetapi gagal. Namun di universitas yang sama dia diberikan posisi mengajar sebagai dosen. Kant mengajar topik dan tema keilmuan yang luas. Tidak hanya Metafisika, logika, dan moral. Kant mengampuh subjek-subjek lain seperti fisika, matematika, geografi, antropologi, pedagogi bahkan mineralogi (Copleston, 1994). Kant dikenal sebagai filsuf melalui karyakaryanya di bidang filsafat moral dan epistemologi. Pada fase kritis karya besar Kant dalam bidang epistemologi yang ditulisnya adalah Critique of Pure Reason (1781). Kant menerbitkan lagi dua karya kritik lainnya yaitu Critique of Pratical Reason (1788) dan Critique of Judgement (1790). Konsentrasi khusus tentang hubungan moral dan filsafat politik termuat dalam karyanya Ground Work of Metaphysics of Moral (1785), To Perpetual Peace (1795) dan Metaphysics of Moral (1797). Karya filsafat politik Kant mencoba menguji ide besar pencerahan secara umum dan secara khusus mengkaji konsep kebebasan. Kerangka dan sistematika gagasan kontrak sosial Kant termuat juga dalam ketiga karya tersebut.

\section{KONTRAK SOSIAL PENJAMIN HAK}

HAM dipahami secara umum oleh akademisi dan aktivis sebagai konsep menyangkut hak atas kesetaraan harkat dan martabat setiap manusia sebagai individu. Secara mendasar HAM tidak hanya terkait dengan kejahatan kemanusiaan berat seperti kasus-kasus yang bahkan sulit diungkap di media arus utama dan publikasi ilmu-ilmu sosial. HAM menyangkut martabat yang mengacu pada hak-hak dasar, kesetaraan dan kebebasan individu. Bebas dari diskriminasi etnis, agama dan kepercayaan. Kebebasan adalah keadaan ketika seorang mengikuti suara hati dan nuraninya tanpa dihalangi dengan alasan apapun. Membahas HAM secara filosofis berarti membahas konsep-konsep dalam filsafat politik dan moral sekaligus. Secara khusus inti pembahasan HAM terletak pada martabat, kebebasan dan kesetaraan. Ketiga prinsip dasar HAM tersebut terjamin apabila ada satu tatanan yang berdasar pada kehendak umum. Tatanan yang menjamin HAM tersebut 
disepakati secara rasional. Tatanan sosial yang disepakati itu berupa perjanjian atau kontrak yang berfungsi menjamin prinsipprinsip dasar HAM. Kontrak sosial dengan demikian relevan menjadi kerangka pemahaman tentang penegakan HAM.

Pemahaman atas kontrak sosial Kantian dapat dimulai dengan meninjau dalil rasionalnya tentang kebebasan. Menurut Kant setiap individu memiliki kebebasan alamiah. Kebebasan yang dimiliki tiap individu membuatnya setara. Kant menyebutnya kesetaraan alamiah (Marey, 2020). Individu yang setara kebebasannya harus mampu menentukan motif dan perilakunya dalam mewujudkan satu masyarakat yang baik. Individu menggunakan rasionalitas praktis untuk menghasilkan kontrak sosial. Kebebasan dan kesetaraan alamiah yang dimiliki individu hanya dapat terjamin oleh semacam pengaturan dan kondisi buatan yang berwujud ikatan sosial yang legal. Kontrak sosial secara longgar dapat dikatakan sebagai ikatan sosial yang merupakan upaya rasional mendirikan satu masyarakat politik yang etis.

Tujuan dari kontrak sosial adalah menghasilkan suatu kondisi masyarakat yang berkeadilan. Kant menyatakan bentuk masyarakat yang ideal adalah republik paripurna (Herzog, 1984; Riley, 1980). Menurut Kant negara ada dari kesediaan individu untuk mendirikannya. Kontrak sosial adalah sikap kerelaan setiap individu menyatukan kehendak menuju kehidupan sosial kemasyarakatan dalam negara. kontrak sosial merupakan penyatuan kehendak tiap individu secara suka rela untuk keluar dari keadaan alamiah (state of nature) masuk ke dalam apa kesatuan sosial yang disebut negara (Marey, 2020). Kontrak versi Kant dimengerti sebagai tindakan sukarela seorang yang dengan kehendaknya menyerahkan kebebasan eksternalnya untuk menjadi satu bagian dari entitas yang disebut negara (Herzog, 1984; Riley, 1980). Kontrak yang dimaksudkan Kant berupa janji dan penerimaan (Kant, 1964, 2019). Kontrak sosial bagi Kant adalah refleksi individu sebagai makhluk rasional. Refleksi dan kehendak menjadi pendasaran dan persetujuan akan negara. Sosial kontrak diartikan sebagai postulat yang dihasilkan manusia sebagai 
makhluk rasional. Makhluk yang secara rasional mencita-citakan satu kehidupan bersama yang etis.

Berbeda dengan pemikir kontrak sosial sebelumnya yakni Hobbes, Locke, dan Rousseau, kontrak sosial versi Kant ada pada level metafisis. Artinya kontrak ada pada tataran kesadaran dan pengetahuan manusia (Williams, 2011). Kontrak sosial pada pemikiran Kant bersumber dari penggunaan rasio praktis. Rasio praktis yang memutuskan maksim tentang masyarakat sipil dan hukum yang mengaturnya. Kontrak sosial dalam pemikiran Kant bersifat abstrak. Kontrak dalam pemikiran Kant berarti pikiran rasional yang melahirkan maksim yang dapat diuniversalkan. Kontrak sosial dilandaskan pada metafisika moral Kant. Negara lantas didasarkan pada kontrak sosial dan penyatuan kehendak tiap individu yang sesuai hukum universal.

\section{Moral Sebagai Landasan Kontrak Sosial}

Pemikiran filsafat politik Kant koheren dengan filsafat moralnya. Memahami kontrak sosial Kant sebagai satu konsep dalam proyek filsafat politik menuntut uraian tentang konsepkonsep moral dasarnya. Bagi Kant manusia adalah makhluk rasional yang menggunakan akal untuk memberi dasar pemahaman bagi tindakannya. Kant membagi modus memperoleh pengetahuan ke dalam dua kategori yaitu rasio teoritis dan praktis. Pengetahuan moral dihasilkan melalui penggunaan rasio praktis. Hukum moral yang dihasilkan lewat rasio praktis bersifat murni dan apriori sebab pikiran tidak bergantung pada hukum kausalitas dan pengalaman empirik. Tindakan dikatakan baik secara moral apabila telah diatur oleh kategori imperatif.

Kant dalam Groundwork for Metaphysics of Moral (1964) mengartikan imperatif kategori sebagai aturan yang ditentukan oleh kewajiban. Peran kerja akal budi menentukan tindakan. Imperatif kategori adalah perintah yang tidak terikat pada akibatnya. Suatu tindakan dinilai baik karena tindakan tersebut baik pada dirinya. Tindakan dilakukan karena baik (Kant, 1964, 
2019). Kant menyebut kategori imperatif sebagai perintah untuk bertindak sesuai dengan maksimmu, sehingga kamu sekaligus dapat mengharapkan maksim tersebut dapat menjadi pedoman umum (Kant, 1964, 2019). Maksim secara sederhana dapat diartikan sebagai prinsip. Setiap tindakan seorang seharusnya dilakukan sesuai maksim subjektifnya. Maksim adalah prinsip subjektif dari kehendak yang adalah hukum praktis (Kant, 1964, 2019). Kehendak dalam pikiran diatur oleh fakultas rasio praktis untuk menghasilkan maksim agar sesuai dengan hukum moral universal.

Kant menegaskan ini dalam karya Critique of Pure Reason bahwa kebebasan diri diatur oleh fakultas pengetahuan yang nantinya memproses respon dan tindakan (Kant, 1958). Manusia merupakan makhluk rasional. Manusia tidak merespon dan bertindak secara impulsif atas pengalaman inderawinya (Kant, 1958). Fakultas pengetahuan bertugas untuk menampung bahan untuk diproses oleh rasio praktis yang kemudian dijadikan maksim. Lewat proses tersebut maka kehendak manusia bisa dikatakan telah diatur menjadi hukum moral formal dan bersifat apriori.

Hukum moral formal dan apriori bertugas menghasilkan maksim yang dapat diberlakukan secara universal. Suatu maksim jika tidak dapat diuniversalkan harus dihindari. Maksim harus sesuai dengan hukum moral yang dapat diuniversalkan. Tindakan yang sesuai dengan hukum moral harus mengikuti panggilan kewajiban. Kewajiban berasal dari rasio bukan perasaan (Kant, 1964, 2019). Kehendak baik tidak bergantung pada tujuan tapi tergantung pada kehendak baik itu sendiri. Tindakan baik menurut Kant adalah tindakan yang berdasar pada kewajiban bukan karena kecenderungan (Kant, 1964, 2019). Suatu tindakan idealnya harus didasarkan pada maksim yang memiliki nilai moral.

Filsafat politik dalam pemikiran Kant merupakan cabang dari filsafat praktisnya. Arti filsafat praktis di sini dimaknai sebagai aspek rasional dari praktik, atau tindakan serta perilaku manusia sebagai makhluk yang bebas dan rasional. Filsafat praktis murni bagi Kant merupakan elemen rasional dari filsafat praktis yang merupakan abstraksi dari yang empirik. Kant menyebutnya juga 
sebagai metafisika moral. Kant menghasilkan basis pemikiran bagi filsafat politiknya dalam karya berjudul Metaphysics of Moral (1797). Pada karya inilah muncul apa yang disebut doktrin hak (right) yang merupakan fondasi filsafat politiknya.

Doktrin tentang hak (doctrine of right) dalam bahasa jerman "recht" berdekatan makna dengan kata keadilan dan hukum. Doktrin hak merupakan konsep penting dalam filsafat politik Kant. Doktrin hak merupakan konsep tentang bagaimana kebebasan eksternal manusia dipahami dan diatur. Kebebasan eksternal adalah kebebasan bertindak seseorang. Kebebasan untuk memilih secara subjektif suatu tindakan tertentu. Suatu tindakan karena didasarkan pada kebebasan subjektif maka ia bersifat kontinjen. Kebebasan eksternal bagi Kant merefleksikan tujuan individuindividu yang beragam (Benson, 1987).

Kebebasan eksternal individu diatur oleh negara melalui hukum. Hukum dalam doktrin hak (doctrine of right) merupakan prosedur untuk mengatur perilaku individu. Negara dengan kekuasaannya dapat berlaku koersif. Namun koersi dalam pengertian Kant bukan koersi fisik, ancaman dan hukuman melainkan batasan resiprokal terhadap kebebasan (Ripstein, 2009). Dengan kata lain negara memberi batasan atas kebebasan eksternal individu. Kebebasan bersifat universal oleh sebab itu perlu dikawal agar tidak terjadi penyalahgunaan. Praktik doktrin hak Kant mewajibkan semua aturan dan hukum didasarkan pada hukum hak universal (law of universal right). Hukum hak universal yang dimaksud adalah keadaan di mana setiap individu sebagai makhluk yang memiliki kebebasan dan kesetaraan alamiah. Dengan pendasaran tersebut maka hukum yang mengatur hak harus juga bersifat universal. Hukum yang mengatur hak berangkat dari hukum moral deontologi. Satu tindakan subjektif yang baik secara moral adalah tindakan yang berdasar pada imperatif kategoris. Itu berarti setiap orang harus bertindak supaya setiap pilihan tindakannya dapat berkoeksistensi dengan kebebasan individu lain. Suatu tindakan agar kompatibel dengan kebebasan yang lain haruslah berdasar pada hukum moral universal. 
Doktrin tentang hak jika disimpulkan terdiri dari tiga prinsip. Pertama, kebebasan bagi setiap individu. Kedua, kesetaraan setiap individu sebagai subjek. Ketiga, otonomi setiap individu untuk menentukan hidupnya tanpa dipaksa oleh orang lain. Gagasan Kant tentang doktrin hak menyaratkan kebutuhan akan aturan agar setiap perilaku dan tindakan individu dalam masyarakat tidak saling melanggar. Kebebasan satu dengan yang lain tidak saling bertentangan. Bagaimana keadaan sosial semacam itu bisa terwujud? Koherensi pemikiran moral Kant dan filsafat politiknya terhubung secara linier. Kontrak sosial versi Kant dipahami dalam korelasi antara filsafat politik dan etika Kant.

\section{Negara Sebagai Yang Berdaulat (The Sovereign)}

Filsafat politik Kant memang tidak mengelaborasi dengan terang konsepsi negara. Kant hanya menyaratkan akan adanya agen yang berdaulat yang mengatasi masyarakat. Agen tersebut berdaulat untuk mengatur kebebasan eksternal tiap individu agar dapat hidup berdampingan (coexist). Negara dianggapnya sebagai agen yang berdaulat yang diharapkan menyempurnakan konstitusi sebagai landasan terciptanya kehidupan sosial yang damai, etis dan berbeda dari keadaan alamiah (Franceschet, 2016). Kepastian jaminan kebebasan eksternal antara individu satu dengan yang lain sulit dibayangkan tanpa adanya negara sebagai yang berdaulat. Individu-individu dapat menyalahgunakan kebebasan eksternalnya dan melanggar kebebasan yang lain sehingga dibutuhkan kedaulatan absolut dalam suatu negara. Tanpa adanya yang berdaulat (sovereign) absolut sulit untuk dibayangkan terwujudnya perlindungan akan hak dan kesetaraan kebebasan (Franceschet, 2016). Kant menyatakan kebutuhan akan kedaulatan dalam karyanya Idea for a Universal History with a Cosmopolitan Purposes (Kant, 2003). Kant menyebutkan bahwa kedaulatan (sovereign) dibutuhkan untuk mengatur kehendak diri agar mematuhi kehendak universal yang valid yang menjamin kebebasan semua orang. 
Kontrak Sosial versi Kant bersifat metafisis. Kontrak dipahami sebagai kesatuan kehendak. Kedaulatan (sovereign) yang dimaksudkan Kant secara sederhana berarti penggunaan rasio praktis menghasilkan kehendak yang dijadikan hukum moral universal untuk mengatur kebebasan eksternal setiap individu di dalamnya. Kedaulatan dalam pemikiran Kant lantas dapat diartikan sebagai berdaulatnya hukum. Lewat hukum perlindungan atas kebebasan eksternal terwujud dan berdasar imperatif moral (Ginsberg, 2016). Manusia sebagai makhluk yang rasional mengaktifkan kapasitas rasio praktis untuk menghasilkan hukum moral universal. Agen moral rasional mengikuti kehendaknya secara otonom. Makhluk yang rasional menentukan tindakannya berdasarkan hakikatnya yang rasional. Manusia yang rasional memperlakukan sesama sebagai tujuan dalam dirinya (Kant, 2019). Individu yang rasional wajib mengikuti dua kewajiban. Pertama, kewajiban meninggalkan keadaan alamiah dan bergabung dengan individu lain membentuk satu masyarakat sipil (Kant, 2019). Kedua, kewajiban untuk tidak pernah menolak dan membantah yang berdaulat (Kant, 2019). Dalam dua kewajiban itu hukum berfungsi sebagai legitimasi koersif kepada tiap individu. Hukum sebagai yang berdaulat dapat dipraktikkan secara koersif oleh negara untuk mengatur agar kebebasan setiap individu dapat kompatibel satu dengan yang lain (Kant, 2019).

Negara dengan legitimasinya dapat bertindak koersif dengan acuan hukum hak universal (universal law of rights). Negara melalui hukum universal mengatur dan menjadi penjaga agar setiap tindakan individu yang bebas sesuai pilihannya dapat selaras (coexist) dan kompatibel dengan kebebasan individu lain sesuai hukum universal. Artinya setiap individu perlu mengatur tindakan dan perilaku sedemikian rupa sehingga memberi ruang bagi yang lain untuk bertindak dan berperilaku tanpa paksaan dan desakan. Kuasa dan hukum yang bersifat koersif memiliki legitimasi hanya jika digunakan untuk memeriksa dan membatasi tindakantindakan yang merusak dan melanggar kebebasan. Legitimasi hukum atas tindakan koersif negara bertujuan merawat keselarasan 
dan kompatibilitas kebebasan eksternal. Negara bertugas menjaga agar perlakuan seorang individu kepada yang lain berdasarkan hak, kebebasan, dan otonomi masing-masing dengan dalil bahwa setiap individu wajib diperlakukan sebagai tujuan pada dirinya sendiri.

\section{KONTRAK SOSIAL DALAM PERTAUTANNYA DENGAN PERLINDUNGAN HAM DI INDONESIA}

Gagasan HAM dalam tradisi filsafat dapat dilacak secara historis dimulai pada semangat pencerahan. Pemikiran Immanuel Kant merupakan salah satu yang memberi justifikasi pada gagasan HAM. Prinsip-prinsip dasar pencerahan yang terhubung dengan HAM secara ketat antara lain adalah hak alamiah berupa kebebasan (freedom), kesetaraan (equality), dan martabat (dignity). Prinsipprinsip pencerahan tersebut mempengaruhi perubahan dan kejadian politik bersejarah dan roh emansipasi di Eropa dan dunia secara umum hingga menemui puncaknya pada deklarasi HAM universal tahun 1948.

Deklarasi HAM universal mematenkan pengakuan terhadap martabat yang melekat pada setiap manusia. Martabat, kebebasan dan kesetaraan menjadi hak-hak yang tidak dapat dicabut (inalienable) dari individu. Martabat dan kesetaraan menjadi prinsip baru bagi dunia untuk menghadirkan kemerdekaan, keadilan dan perdamaian dunia. Kant menekankan HAM pada martabat, kesetaraan, dan kebebasan. Martabat yang menjadi prinsip dasar bersumber dari kapasitas otonomi seorang untuk menentukan tujuan dalam dirinya (Bayefsky, 2013). Martabat tersebut sesuai dengan basis pemikiran filsafat moral Kant yang berangkat dari intensi subjektif yang diputuskan secara formal. Martabat seseorang itu dinilai dan diukur berdasarkan tindakan seseorang memperlakukan orang lain sebagai tujuan dalam dirinya. Individu diandaikan hidup dalam komunitas rasional yang menentukan prinsip moral untuk mengatur kesetaraan dan otonomi setiap individu itu. HAM dari perspektif filsafat politik dan etika Kant didasarkan pada kepercayaan atas individu rasional yang otonom. 
Hal ini berarti bahwa penegakan HAM dari perspektif Kant berarti perlindungan atas martabat manusia. Perlindungan atas HAM juga berasal dari otoritas akal budi manusia. Prinsip dasar moral bagi justifikasi HAM pada Kant bersumber dari kategori imperatif sebagai prosedur akal budi yang menentukan dasar tindakan moral.

Prinsip universalitas dalam HAM merupakan produk kehendak moral yang rasional. Penegakan HAM dapat terwujud secara maksimal bila didasarkan oleh kehendak baik. Penegakan HAM seharusnya berangkat dari kehendak dan tindakan negara untuk menuntaskan kasus di masa lalu, menekan jumlah kasus di masa sekarang dan bertekad bulat melindungi HAM di masa mendatang. Hambatan umum penegakan HAM tampak bersumber dari belum adanya kehendak politik (political will) dan praktik kebijakan konkret untuk menyelesaikan kasus dimasa lalu, menegakkan HAM dimasa sekarang, dan merencanakan perbaikan aksi penegakan HAM secara nasional di masa depan. Tugas penegakan HAM lewat penyelesaian kasus berat masa lalu dapat diwujudkan jika ada rasa kemanusiaan, keadilan, kesadaran hukum, demokrasi, serta kualitas moral politik pada nalar penguasa.

HAM dan demokrasi dapat disebut sebagai konsep kembar. Meskipun dalam sejarahnya kemunculannya berasal dari trajektori yang berbeda keduanya selalu terkait erat (overlapping). Demokrasi dan HAM secara historis beriringan dalam isu perjuangan akan hak warga negara. Pemahaman akan HAM juga menyaratkan pemahaman tentang kepentingan warganegara dalam konteks negara hukum demokratis. HAM dan demokrasi bekerja di atas prinsip yang sama yakni inklusivitas, partisipasi, akuntabilitas, integritas individu, representasi yang setara dan berkeadilan, serta solusi sosial tanpa kekerasan (non-violent) (Landman, 2013, 2018). Demokrasi mengandaikan HAM, dan HAM terkait erat dengan demokrasi karena partisipasi rakyat dan kendali rakyat atas kehidupan politik menentukan hak sipil dan hak politik. Demokrasi yang ideal sudah pasti menjamin hak asasi. Demokrasi substansial 
memberi jaminan hak-hak berkeyakinan, bergerak, berkumpul, berekspresi, berorganisasi yang darinya muncul representasi dan partisipasi dalam kehidupan sosial politik, ekonomi dan budaya warga.

Dua dekade sejak reformasi hambatan penegakan HAM dan penyelesaian kasus pelanggaran HAM berjalan lambat dan lemah. Dalam transisi pasca rezim militer otoriter kesulitannya berlapis sebab terkait dengan relasi kuasa elit-elit militer Orde Baru di pemerintahan. Kondisi tersebut sejalan dengan tesis Samuel Huntington tentang transisi demokrasi. Menurut Huntington fase transisional merupakan fase berat. Beberapa masalah utama dalam proses transisi demokrasi antara lain, reformasi politik militer, penyelesaian pelanggaran atas HAM masa lalu dan proses membangun fondasi bagi kebudayaan politik demokratis (Robet, 2014).

Lemahnya penegakan HAM juga berangkat dari dilema pemerintah dalam menerapkan prinsip-prinsip HAM. Prinsipprinsip dalam HAM telah termuat dalam konstitusi namun dalam praktik terhambat oleh politik kekuasaan. Penegakan HAM masih lemah jika berhadapan dengan kekuasaan. Keadaan tersebut dapat dilihat sepanjang dua dekade perjalanan demokratisasi di Indonesia. Komnas HAM sebagai komisi yang menjalankan fungsi pengkajian, penyuluhan, dan pemantauan HAM bahkan sampai memberikan rapor merah kepada pemerintah pada akhir tahun 2019. Kasus-kasus pelanggaran HAM berat belum terselesaikan dan diperburuk dengan munculnya kasus kriminalisasi warga. Banyak terjadi konflik lahan perkebunan dan kehutanan. Selain itu penegakan hukum yang lemah menjadi lahan subur bagi munculnya kasus intoleransi. Pelanggaran atas hak dan kebebasan berekspresi juga beriringan dengan banyaknya kasus intoleransi seperti, pelanggaran atas kebebasan berkeyakinan dan beragama. Fenomena tersebut memperburuk citra penegakan HAM di Indonesia.

Gagasan kontrak sosial Kant yang telah dibahas pada bagian sebelumnya dimaksudkan untuk merangkai kembali perspektif 
moral dan etika politik bagi penegakan HAM. Elaborasi sudut pandang moralitas politik tersebut dilakukan dengan maksud meninjau peran negara untuk menjaga martabat individu. Dalil tentang otonomi, hak, dan kebebasan yang setara dimiliki setiap orang merupakan produk rasio praktis dalam menghasilkan hukum moral yang universal untuk mendasari fungsi negara. HAM dengan demikian dari pandangan kontrak sosial Kant dapat dianggap sebagai hasil penyatuan kehendak (unified will) yang merupakan buah dari rasio praktis yang kemudian menghasilkan dasar-dasar moral tentang Hak dan kebebasan alamiah yang setara. Untuk menjamin penegakan HAM perlu difungsikan doktrin hak (doctrine of right). Sesuai dengan doktrin hak, negara dan konstitusi memiliki peran sekaligus merupakan implementasi dari kontrak sosial. Negara bertugas merawat batasan resiprokal kebebasan individu-individu di dalam negara. Artinya negara menjamin agar setiap individu dalam kebebasannya dapat hidup berdampingan (coexist) tidak melanggar HAM satu sama lain. Kontrak sosial bagi Kant merupakan buah dari hukum moral universal yang bersifat imperatif kategoris. Artinya moral deontologi dipakai untuk menghasilkan kontrak sosial. Prinsip-prinsip dasar HAM dapat dikatakan sebagai isi kontrak sosial tersebut.

Berangkat dari pemikiran Kant bahwa kontrak sebagai penyatuan kehendak moral setiap individu maka tidak cukup hanya menyerahkan penegakan HAM kepada pemerintah. Perlu ada perluasan wacana HAM lewat sosialisasi dan pendidikan HAM kepada setiap individu sebagai publik yang akan menghasilkan kehendak atau kontrak sosial. Setiap individu adalah subjek-subjek yang menerapkan imperatif moral, menghasilkan kontrak dan kemudian menyatukan kehendaknya. Sesuai dengan doktrin hak (doctrine of right) Kant, kebebasan, kesetaraan, dan otonomi merupakan prinsip dasar HAM. Prinsip-prinsip dasar ini juga harus melandasi praktik perbaikan penegakan HAM. Secara implementatif hal tersebut berarti bahwa perlu ada upaya agar publik Indonesia semakin memahami hak-hak dasarnya sebagai individu dan sekaligus hak-haknya sebagai warga negara. Tiap 
individu warga negara wajib memahami dan memperjuangkan status dan fungsi hak serta kebebasannya.

Selain hal tersebut di atas, pokok lain yang juga patut diperhatikan adalah bahwa negara melalui kebijakan yang menjunjung tinggi supremasi hukum wajib merawat kondisi agar hak dan kebebasan tidak disalahgunakan dan mencederai HAM. Prinsip moral wajib mendasari praktik hukum. Prinsip moral dasar dalam arti Kantian tidak lain adalah maksim universal yakni memperlakukan orang lain sebagai tujuan dalam dirinya. Artinya kebebasan setiap individu tidak boleh dicederai sebab merupakan hak asasi yang melekat padanya. Setiap manusia adalah otonom dan hanya menjadi tujuan dalam dirinya. Negara memiliki legitimasi bertindak koersif hanya kepada mereka yang mengancam kebebasan dan hak orang lain. Koersif dalam arti Kantian adalah upaya merawat keselarasan, keharmonisan, kompatibilitas kebebasan eksternal antar indvidu. Dengan kata lain koersi disini bukan tindakan yang justru menghilangkan kebebasan tapi untuk menjaga hak asasi dasar seperti kebebasan, kesetaraan dan martabat tiap manusia. Pasal-pasal dalam konstitusi mengenai HAM adalah dasar legitimasi penegakan hukum dan tindakan koersif negara. Praktik koersi negara lewat hukum dalam skala prioritas berfungsi menjaga dan menjamin kompatibilitas kebebasan tiap individu agar tidak dilanggar oleh siapapun dengan alasan apapun.

Berdasarkan uraian tersebut di atas maka dapat disimpulkan bahwa kontrak sosial Immanuel Kant merupakan penyatuan kehendak (unified will). Setiap individu bersama-sama menyatukan kehendaknya menjaga kebebasan tiap subjek agar tidak melanggar satu dengan yang lain. Kontrak sosial menjadi justifikasi dan dasar bagi eksistensi negara. Dengan kata lain, jika negara melalui aparatur pemerintah tidak dapat menjamin martabat dan HAM dari warganya maka dengan sendirinya kontrak sosial telah dinegasikan. Negara lewat pemerintah sebagai agen yang berdaulat (the sovereign) seharusnya menjadi penjamin dan penegak HAM. Negasi atas HAM merupakan negasi atas kontrak sosial. Jika hal 
tersebut terjadi maka harapan tentang masyarakat politik yang bermartabat yang menjaga hukum moral universal akan sirna.

Terjadinya pelanggaran HAM merupakan kondisi yang tidak sesuai dengan prinsip-prinsip etika politik dalam kontrak sosial Kant. Terhambatnya penegakan HAM dalam konteks Indonesia terjadi karena faktor politik hukum dan kontestasi kekuasaan. Elit politik dan penguasa belum bekerja berdasarkan tujuan kontrak sosial yakni melindungi HAM setiap individu dan kelompok masyarakat. Kondisi tersebut juga menunjukkan bahwa praktik kekuasaan di dalam sistem politik Indonesia pasca reformasi belum maksimal sehingga berakibat pada lemahnya penegakan HAM itu sendiri.

\section{SIMPULAN}

Kontrak sosial dalam pemikiran Kant bersifat metafisik dalam arti merupakan penyatuan kehendak (unified will). Kontrak sosial dalam filsafat politik Kant linier dengan filsafat moralnya. Kontrak dalam filsafat politik Kant dimaksudkan menjadi dasar bagi kehidupan sosial politik yang berlandaskan hukum moral universal. Kontrak menjadi dasar dan justifikasi bagi hukum dan legitimasi koersi negara. Masyarakat politik adalah masyarakat yang berdasarkan hukum yang menjamin kebebasan eksternal antar individu. Setiap kebebasan eksternal diatur agar dapat saling berkoeksistensi. Kebebasan dan kesetaraan yang alamiah yang inheren dalam diri individu wajib dijamin oleh negara sebagai perwujudan dari kontrak sosial.

Pelanggaran HAM yang masih terjadi pasca reformasi yang berakumulasi dengan beban hambatan penyelesaian kasus HAM berat masa lalu menunjukkan bahwa proses penegakan HAM di Indonesia masih lemah sampai dengan hari ini. Kenyataan atas lambannya progres penegakan HAM di Indonesia ini menunjukkan perlunya komitmen baru dan kesatuan kehendak yang luas oleh seluruh elemen masyarakat sipil, elit politik, dan lembaga-lembaga pemerintah maupun non-pemerintah untuk bekerja meningkatkan dan mempercepat kualitas penegakan HAM. Hal tersebut akan 
berjalan maksimal seiring dengan proses demokratisasi yang terjadi di Indonesia karena alam demokrasi yang secara substansial sehat dengan sendirinya membentuk kondisi perlindungan dan penegakan HAM.

\section{DAFTAR PUSTAKA}

Aswandi, B., \& Roisah, K. (2019). Negara hukum dan demokrasi pancasila dalam kaitannya dengan hak asasi manusia (HAM). Jurnal Pembangunan Hukum Indonesia, 1(1). https://doi.org/10.14710/jphi.v1i1.128-145

Azhar, H. (2014). The human rights struggle in indonesia: International advances, domestic deadlocks. Sur, 11(20).

Bayefsky, R. (2013). Dignity, Honour, and Human Rights: Kant's Perspective. Political Theory, 41(6). https://doi.org/10.1177/0090591713499762

Benson, P. (1987). External Freedom according to Kant. Columbia Law Review, 87(3). https://doi.org/10.2307/1122671

Bertens, K. (1975). Sejarah Filsafat Yunani. Kanisius. Budiardjo, M. (1981). Dasar-Dasar Ilmu Politik. Gramedia.

Copleston, F. (1994). A History of Philosophy. Vol. 6. Modern Philosophy: From the French Enlightenment to Kant. In Doubleday (Vol. 6, Issue March).

Deti, M. P. (2019). Kaleidoskop 2019 Catatan Komnas HAM Untuk Pemerintah Terkait Hak Asasi. www.nasional.kompas.com/read/2019/12/24/20042321/kaleid oskop-2019-catatan-komnas-ham-untuk-pemerintah-terkaithak-asasi?page $=$ all

Donnelly, J. (2019). Universal Human Rights in Theory and Practice. In Universal Human Rights in Theory and Practice. https://doi.org/10.7591/9780801467493

Egi. (2018). Catatan Kritis Empat Tahun Pemerintah Joko Widodo. www.komnasham.go.id/index.php/news/2018/10/19/647/catat an-kritis-empat-tahun-pemerintahan-joko-widodo.html

El-Muhtaj, M. (2015). Hak Asasi Manusia dalam Konstitusi Indonesia. Kencana. 
Franceschet, A. (2016). Kant and Liberal Internationalism: Sovereignty, Justice and Global Reform. In Kant and Liberal Internationalism: Sovereignty, Justice and Global Reform. https://doi.org/10.1007/978-1-137-07853-7

Freeman, M. (1994). The Philosophical Foundations of Human Rights. Human Rights Quarterly, 16(3). https://doi.org/10.2307/762434

Ginsberg, R. (2016). Kant and Hobbes on The Social Contract. The Southwestern Journal of Philosophy, 5(1).

Gordon, J. (2017). The concept of Human Rights: The history and meaning of its politicization. In Human Rights. https://doi.org/10.4324/9781315199955-3

Hamid, U. (2006). Isu-isu HAM di Indonesia. Seminar $\mathcal{E}$ Workshop Pendidikan Hak Asasi Manusia.

Herzog, D. (1984). Will and Political Legitimacy: A Critical Exposition of Social Contract Theory in Hobbes, Locke, Rousseau, Kant, and Hegel. Patrick Riley . The Journal of Politics, 46(1). https://doi.org/10.2307/2130446

Kant, I. (1958). Critique of Pure Reason. Bobbs-Merril.

Kant, I. (1964). Groundwork of the Metaphysics of Moral. Harper \& Row, New York.

Kant, I. (2003). Idea for a universal history with a cosmopolitan purpose. In The Civil Society Reader. https://doi.org/10.1017/cbo9780511809620.004

Kant, I. (2019). The Metaphysics of Morals. In Kant: Political Writings. https://doi.org/10.1017/cbo9780511809620.008

Landman, T. (2013). Human Rights and Democracy. Bloomsbury, New York.

Landman, T. (2018). Democracy and human rights: Concepts, measures, and relationships. Politics and Governance, 6(1). https://doi.org/10.17645/pag.v6i1.1186

Marey, M. (2020). Kant's popular sovereignty and cosmopolitanism. Constellations, 27(3). https://doi.org/10.1111/1467-8675.12453 
Putra, M. A. (2016). Perkembangan muatan HAM dalam konstitusi di Indonesia. FIAT JUSTISIA:Jurnal Ilmu Hukum, 9(2). https://doi.org/10.25041/fiatjustisia.v9no2.597

Rapar, J. (1993). Filsafat Politik Aristoteles. Raja Grafindo Persada.

Riley, P. (1980). Will and Political legitimacy, A Critical Exposition of Social Contract Theory in Hobbes, Locke, Rousseau, Kant, and Hegel. Harvard University Press.

Ripstein, A. (2009). Force and Freedom, Kant's Legal and Political Philosophy. Harvard University Press.

Robet, R. (2014). Politik Hak Asasi Manusia dan Transisi di Indonesia, Dari Awal Reformasi hingga Akhir Pemerintahan SBY. ELSAM.

Russel, B. (1945). History of Western Philosophy. Simon \& Schuster George Allen \& Unwin Ltd.

Schmandt, H. J. (1960). A History of Political Philosophy. The Bruce Publishing Company.

Utari. (2020). Penegakan HAM di Indonesia belum mengalami Kemajuan. https://www.komnasham.go.id/index.php/news/2020/7/13/14 80/penegakan-ham-di-indonesia-belum-mengalamikemajuan.html

Williams, H. (2011). Metaphysical and not just Political, Politics and Metaphysics in Kant. University of Wales Press. 